\title{
РОЛЬ МЕДИЧНОЇ СЕСТРИ В ПРОФІЛАКТИЦІ АРТЕРІАЛЬНОЇ ГІПЕРТЕНЗІЇ
}

\author{
Л. Я. Вербіцька, С. О. Ястремська \\ КЗ ТОР «Тернопільська університетська лікарня» \\ ДВНЗ «Тернопільський державний медичний університет \\ імені І. Я. Горбачевського МОЗ Украйни"
}

\begin{abstract}
Гіпертонічна хвороба - це найпоширеніше хронічне захворювання серцево-судинної системи, яке уражає людей працездатного віку і призводить до розвитку тяжких ускладнень та інвалідизації. Контроль артеріального тиску - один з основних моментів лікування артеріальної гіпертензії. В цьому аспекті важлива роль відводиться роботі медичної сестри з пацієнтами. У даній статті показано переваги медсестринського догляду за хворими 3 гіпертонічною хворобою разом у команді 3 лікарем.
\end{abstract}

\section{ROLE OF NURSES IN THE PREVENTION OF ARTERIAL HYPERTENSION}

\author{
L. Ya. Verbitska, S. O. Yastremska \\ MI of TRC «Ternopil University Hospital»
}

SHEI «Ternopil State Medical University by I. Ya. Horbachevsky of MPH of Ukraine»

\begin{abstract}
Hypertension is the most common chronic disease of cardiovascular system, which affects people of working age and leads to serious complications and disability. Control of blood pressure - one of the methods of treatment of arterial hypertension and role of nurses in this process is very important. This article demonstrates the advantages of nursing care of patients with hypertension together with doctor.
\end{abstract}

Вступ. Артеріальна гіпертензія (АГ) залишається однією з найактуальніших проблем охорони здоров'я більшості кра н, у тому числі й Укра ни. Це пов'язано з тим, що АГ є одним 3 найголовніших факторів ризику серцево-судинних захворювань і зумовлено нею смертності. В 2010 році в Украні зареєстровано майже 12 млн хворих на артеріальну гіпертензію. За даними МОЗ Укра ни, поширеність АГ склала $31,5 \%$, що повністю відповідає результатам епідеміологічних досліджень, згідно з якими стандартизований за віком показник поширеності АГ серед міського населення становить $29,6 \%$, в сільській популяці - 36,3\% [1].

Згідно з рекомендаціями Укра нсько асоціаці кардіологів із профілактики та лікування артеріально гіпертензі - 2011 рік, виділяють величини нормального і підвищеного артеріального нормального тиску, види і ступені тяжкості артеріально гіпертензі (табл. 1).

(ㄱ Л. Я. Вербіцька, С. О. Ястремська, 2015
Таблиця 1. Класифікація артеріальної гіпертензї за рівнем AT

\begin{tabular}{|l|l|l|}
\hline \multicolumn{1}{|c|}{ Категорія } & \multicolumn{1}{c|}{$\begin{array}{c}\text { САТ } \\
\text { мм рт. ст. }\end{array}$} & $\begin{array}{c}\text { ДАТ } \\
\text { мм рт. ст. }\end{array}$ \\
\hline Оптимальний & $<120$ & $<80$ \\
\hline Нормальний & $<130$ & $<85$ \\
\hline Високий нормальний & $130-139$ & $85-89$ \\
\hline Гіпертензія: & & $90-99$ \\
\hline 1 ступінь & $140-159$ & $100-109$ \\
\hline 2 ступінь & $160-179$ & $>110$ \\
\hline 3 ступінь & $>180$ & $<90$ \\
\hline $\begin{array}{l}\text { Ізольована систолічна } \\
\text { гіпертензія }\end{array}$ & $\geq 140$ & \\
\hline
\end{tabular}

Основна частина. На сьогодні все більше уваги приділяють профілактиці виникнення і розвитку захворювання. В цьому не останню роль відіграє робота медично сестри з пацієнтами. У даний час в медичних установах існують 
«школи здоров'я» для пацієнтів з різними захворюваннями (гіпертонічна хвороба (ГХ), цукровий діабет, бронхіальна астма та інші). Наше дослідження проходило в одній з таких «шкіл» для пацієнтів із серцево-судинними захворюваннями у К3 ТОР «Тернопільська університетська лікарня».

Для вирішення завдання дослідження було проведено анкетування пацієнтів з гіпертонічною хворобою, які відвідують «школу здоров'я», до і після закінчення курсу занять. Пацієнтів розподілили за тяжкістю перебігу гіпертонічно хвороби.

Головна роль у вирішенні проблем пацієнта з АГ належить немедикаментозному та медикаментозному лікуванню, спрямованому на нормалізацію артеріального тиску, зміну вираженості або зникнення несприятливих клінічних проявів гіпертонічно хвороби і супутніх захворювань, поліпшення якості життя і зниження смертності [1, 2]. Медсестра разом із лікарем, пацієнтом і членами його сім' бере участь у заходах щодо попередження розвитку (первинна профілактика) та уповільнення прогресування (вторинна профілактика) гіпертонічно хвороби.

При плануванні догляду медсестра інформує пацієнта і членів його сім' про суть захворювання, загальні принципи його попередження і лікування, організаці психологічно, фізично, соціально та економічно допомоги хворому з боку родичів та заходи щодо зміни звичного для нього стилю життя. Вона закликає хворого до співпраці, навчає його прийомам самодогляду та збереження особисто безпеки, зміцнює віру в безпеку та ефективність лікувальних заходів.

Організовані при поліклініках «школи» полегшують завдання медсестри, допомагають у роботі з пацієнтами. Завданням даних “шкіл" $\epsilon$ :

- оптимізація, удосконалення та підвищення охоплення, доступності та якості медично профілактично допомоги населенню, зокрема пацієнтам 3 артеріальною гіпертензією;

- підвищення інформованості пацієнтів 3 гіпертонічною хворобою про захворювання та його чинники ризику;

- підвищення відповідальності пацієнта за збереження свого здоров'я;

- формування раціонального та активного ставлення пацієнта до захворювання, мотиваці до оздоровлення, прихильності до лікування та виконання рекомендацій лікаря;

- формування у пацієнтів умінь і навичок 3 самоконтролю за станом здоров'я, надання першо долікарсько допомоги у випадках загострень і криз;
- формування у пацієнтів навичок і вмінь щодо зниження несприятливого впливу на хнє здоров'я поведінкових факторів ризику, харчування, рухово активності, керування стресом, відмови від шкідливих звичок;

- формування у пацієнтів практичних навичок з аналізу причин, чинників, що впливають на здоров'я, і навчання пацієнтів складання індивідуального плану оздоровлення.

Провівши анкетування 60-ти слухачів «школи" було встановлено поділ за статтю та віком (рис. 1).

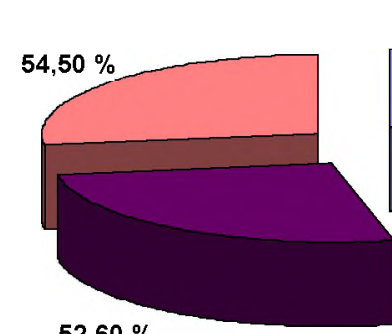

$52,60 \%$
$18,20 \%$

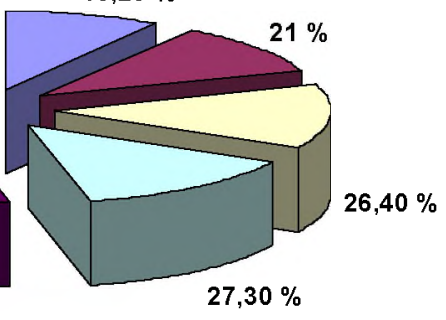

$\square 1 \square 2 \square 3 \square 4 \square 5 \square 6$
Рис. 1. Розподіл пацієнтів за статтю та віком:

1 - чоловіки 40-49 років (4 особи); 2 - чоловіки, старші 60 років (6 осіб); 3 - жінки, старші 60 років (8 осіб); 4 - жінки 40-49 років (10 осіб); 5 - чоловіки 50-60 років (12 осіб); 6 - жінки 50-60 років (20 осіб).

Аналізуючи результати опитування констатуємо, що серед респондентів переважають пенсіонери - 32 (53,3\%), далі робітники - 18 (30\%) і службовці - 10 (16,7 \%).

На розвиток, прогресування і смертність від серцево-судинних захворювань впливає безліч природних і соціальних факторів, що мають назву факторів ризику. В першу чергу, це спосіб життя, який визначає стан здоров'я на 50-55\%, стан навколишнього середовища, генетичні особливості людини і рівень медично допомоги. 3 позиці модифікаці цих факторів ризику за допомогою профілактичних програм найбільш важливими $\epsilon$ артеріальна гіпертензія, зловживання алкоголем, куріння, нераціональне харчування, ожиріння і низька фізична активність. До цих факторів, що є загальними для більшості економічно розвинених кра н, в нашій кра ні додаються психосоціальні фактори, які також негативно впливають на здоров'я населення [3, 4]. Поряд із перерахованими факторами ризику, які умовно можна назвати змінними, оскільки вони можуть піддаватися корекці, виділяють ті, які не піддаються корекці незмінні. х також необхідно враховувати при прогнозуванні розвитку та прогресуванні гіпер- 
тонічно хвороби у кожного індивідуума: вік, стать, генетичні особливості $[5,6]$.

Аналіз анкет пацієнтів показав вплив навчання в “школі здоров'я» на спосіб життя, звички опитаних. Однією з них $є$ тютюнокуріння, від якого дуже неохоче і ледь відмовляються пацієнти. Так, до навчання курили 16 (72,7\%) чоловіків, 12 (31,5 \%) жінок, після - 12 (54,5 \%) чоловіків і 10 (26,3\%) жінок. Від куріння після навчання відмовилися лише 6 осіб.

Аналізуючи, як вплинуло навчання на вживання алкоголю пацієнтами, видно, що до занять вживали алкоголь 18 (81,8\%) чоловіків і $20(52,6 \%)$ жінок, після $10(45,4 \%)$ чоловіків та $8(21 \%)$ жінок.

Один з факторів ризику, надлишкову масу тіла, мають $60 \%$ опитаних. Але вони готові боротися 3 цією проблемою в майбутньому.

Ще один грізний ворог гіпертонічно хвороби - це кухонна сіль. Результати дослідження показали, що до навчання більше 5 г на добу кухонно солі вживали в жу 54 (90\%) опитаних. Після занять ця цифра знизилася до $43 \%-26$ осіб.

За результатами анкет до навчання регулярно контролювали свій АТ 20 осіб (33,3\%) опитаних, нерегулярно - 26 осіб (43,3\%), зовсім не контролювали 14 осіб (23,4 \%). Після навчання регулярно контролюють АТ 40 осіб (66,6 \%), нерегулярно - 14 осіб $(23,4 \%)$, зовсім не контролюють -6 осіб (10\%).

\section{ЛITEPATУРA}

1. Оцінка ефрективності «Програми проффілактики і лікування артеріальної гіпертензії в Україні» за даними епідеміологічних досліджень / І. М. Горбась, О.О.Смирнова, І. П. Кваша, А. П. Дорогой / / Артериальная гипертензия. - 2010. - № 6 (14). - С. 51-67.

2. Кобалава Ж. Д. Повышение приверженности и мотивации к антигипертензивной терапии у больных артериальной гипертонией с помощью образовательных программ и рационального применения ингибитора ангиотензинпревращающего фермента периндоприла. Результаты исследования ПРИЗМА / Ж. Д. Кобалава, С. В. Виллевальде, Х. В. Исикова / / Кардиология. - 2010. - T. 50, № 11. - C. 17-25.

3. Physical activity and risk of stroke in women / J. R. Sattelmair, T. Kurth, J. E. Buring [et al.] / / Stroke. 2010. - Vol. 41. - P. 1243-1250.
На питання, кому пацієнти більше довіряють у питаннях свого здоров'я, були отримані відповіді, що все ж таки більшість людей довіряє медичним працівникам (медичним сестрам) - 32 особи (53,3 \%), по 12 осіб (20\%) довіряють медичній літературі і засобам масово інформаці , відповідно, а 4 особи (6,7 \%) взагалі нікому не довіряють.

Загалом, навчання в “школі здоров'я» пішло пацієнтам на користь. У результаті зниження ймовірності факторів ризику знижується і ризик ускладнень.

Висновки. Результати дослідження показали, що пацієнти, які перебувають на лікуванні в стаціонарі К3 ТОР «Тернопільська університетська лікарня» 3 діагнозом ГХ, досить добре інформовані про своє захворювання, м відомі: симптоми гіпертонічно хвороби, ускладнення та заходи профілактики ускладнень ГХ, Фактори ризику розвитку ускладнень.

Дослідженням встановлено, що значення роботи медично сестри щодо профілактики артеріально гіпертензі значне. У результаті навчання в опитаних знизився ризик розвитку ускладнень, завдяки зменшенню ді факторів ризику. У зв'язку з необхідністю посилення роботи з профілактики ускладнень ГХ, був запропонований ряд заходів, виконуваних медичними сестрами на базі КЗ ТОР «Тернопільська університетська лікарня".

4. Радченко Г. Д. Профрілактика серцево-судинних захворювань: що знають про своє здоров'я лікарі, які займаються лікуванням пацієнтів з артеріальною гіпертензією / Г. Д. Радченко, І. М. Марцовенко, Ю. М. Сіренко / / Артериапьная гипертензия. - 2011. - № 1 (15). C. $37-42$.

5. Коваленко В. М. Виконання Державної програми боротьби з гіпертензіями в Україні / В. М. Коваленко, В. М. Корнацький // Український кардіологічний журнал. - 2010. - № 6. - С. 7-12.

6. Черняга-Ройко У. П. Варіабельність артеріального тиску - стратегічна мішень комбінованої антигіпертензивної терапії чи міфр експериментальних досліджень? / У. П. Черняга-Ройко, М. С. Сороківський // Здоров'я України. - 2012. - № 1. - С. 1-3. 